\title{
Intensive Mode Teaching of a Humanitarian Engineering Course to Enhance Service-Learning
}

\author{
Jeremy Smith \\ The Australian National University \\ Canberra, ACT, Australia 2601 \\ jeremy.smith@anu.edu.au \\ Sally Male \\ The University of Western Australia \\ Perth, WA, Australia 6009
}

\author{
Paul Compston \\ The Australian National University \\ Canberra, ACT, Australia 2601
}

Caroline Baillie

The University of Western Australia

Perth, WA, Australia 6009

\author{
Jennifer Turner \\ Engineers Without Borders Australia \\ Melbourne, Victoria, Australia 3011
}

\begin{abstract}
Service-learning is a common component of many humanitarian engineering education programs. Students engage with external organisations and communities, often spending time intensively, on projects linked to their studies. To help prepare students for substantial service-learning initiatives a dedicated humanitarian engineering course was developed. To better represent service-learning and enable a greater variety of teaching and learning activities, the course was delivered over five weeks using intensive mode teaching. This enabled a portion of the class to be involved with a two-week scaffolded immersive international experience running in parallel to the campus delivery. Threshold concept and capability theory was used to evaluate the course and identify what elements of the course supported or hindered development of student thresholds. Results identified the main student threshold to be the ability to take account of social factors in engineering design and the activities enabled by the intensive mode teaching were among the strongest contributions to the achievement of this threshold, in particular elements of the international experience. This highlights the opportunities for intensive mode teaching in supporting activities related to servicelearning.
\end{abstract}

Index Terms - Humanitarian engineering, intensive mode teaching, threshold concepts

\section{INTRODUCTION}

Service-learning is a component of most humanitarian engineering education programs and can take the form of field work ${ }^{1,2}$, international immersions ${ }^{3}$, capstone projects ${ }^{4}$ or across disciplines and year levels ${ }^{5}$. In addition to providing motivation, which is linked to better learning outcomes, service-learning has been shown to lead to more positive attitudes towards social responsibility ${ }^{7}$, identity outcomes ${ }^{8}$ and civic leadership ${ }^{9}$. Introducing student engineers to service-based projects and community development work can be challenging but is required to ensure students act responsibly, particularly in later years when they may have greater roles ${ }^{4}$.

To provide appropriate preparation for students progressing to more substantial servicelearning experiences, a dedicated mid-program course focusing on humanitarian engineering was developed. To support this and enable activities more representative of service-learning 
it was decided to adopt an intensive mode teaching delivery. This allowed delivery of the course to two parallel cohorts, one campus-based the other utilising a short-term immersive international experience. A threshold concepts and capabilities framework was used to evaluate the student experience and outcomes through this teaching mode to assess the delivery method.

This paper first outlines the context and background for the work, including humanitarian engineering, service-learning and intensive mode teaching. The theoretical framework used to evaluate the intensive teaching mode, based on threshold concepts and capabilities, along with the research questions, is provided. The development of the course is outlined as well as data collection methods. Results and discussion are provided across the various data collection methods within the context of the course and theoretical framework with recommendations for other institutions and researchers.

\section{CONTEXT AND BACKGROUND}

\section{Humanitarian Engineering Education}

Humanitarian engineering education has grown rapidly since the early 2000's with established programs in the $\mathrm{US}^{4}$ and $\mathrm{UK}^{10}$ and emerging programs in Australia ${ }^{11}$ and New Zealand. Related areas with intersecting elements but different philosophical frameworks including engineering for development ${ }^{1}$, global engineering ${ }^{3}$ and engineering for social justice $^{12}$ have also emerged. A discussion of the differences between these is beyond the scope of this paper, however some critiques of humanitarian engineering have explored potential "engineering for development" elements. Broadly, humanitarian engineering initiatives are seeking to prepare graduates to work on humanitarian development and response challenges and opportunities primarily with vulnerable, marginalised or disadvantaged groups or individuals. This places a strong emphasis on professional skills particularly team-work, cross-cultural competency and communication as well as interdisciplinary studies. Critiques of this field particularly from a social justice perspective have considered an inappropriate focus on technology, exclusion of social and power imbalances and lack of consideration of structural forces ${ }^{12}$.

\section{Service-Learning}

To provide opportunities for authentic learning and support humanitarian engineering education, most include a component of service-learning. These seek to provide an opportunity for students to learn course material and content while providing a "service" for an external community or partner, often a non-for-profit organisation. The student activity contributes to credit-bearing courses which provides the scaffold for assessment, feedback and reflection ${ }^{7}$. Students engage directly with external partners on an identified project and need, often spending significant time on activities outside formal class hours ${ }^{13}$. Servicelearning initiatives are being incorporated more broadly into engineering education as a realistic and effective way for students to apply the theory of their studies to encourage deep learning and motivation as well as supporting academic and personal development ${ }^{6,7,14}$.

As with humanitarian engineering, critiques of service-learning have considered advantages and limitations with the approach. In particular, questions of who benefits most and who provides the resources and commitments have been raised ${ }^{15}$. International servicelearning experiences have been examined and placement specific liabilities identified ${ }^{15}$, often linked to elements of social justice ${ }^{12}$. 


\section{Humanitarian Engineering Education Pathway}

Although not offering a formal qualification in humanitarian engineering, The Australian National University (ANU) has established a pathway for students to be involved in activities across all year levels. The ANU is a research intensive university on a single urban-campus established after the second world war with a low staff to student ratio and a significant focus on postgraduate studies. The four-year undergraduate engineering degree has a common systems engineering core, with a number of discipline majors in newer fields including renewable energy, mechatronics and communication.

For a number of years ANU has utilised service-learning through the EWB (Engineers Without Borders Australia) Challenge in first year, local project opportunities in second year, and capstone individual research and group design projects in final year. Leading into capstone experiences a perceived gap with students lacking background in humanitarian approaches and aspects of human-centred and participatory design had been observed. To fill this, and support student interest, a mid-program course on humanitarian engineering was proposed. This would cover humanitarian approaches, appropriate technology, and topics required for in-depth service-learning experiences in later years. While in development EWB launched its Humanitarian Design Summit program, two-week immersive trips to South-East Asian countries EWB worked in. These provide a scaffolded opportunity for students to be involved in development and humanitarian work supported by professional engineers and mentors ${ }^{16}$. Considering the objectives of the course and the opportunities for including the EWB Summits, it was decided to deliver the course using intensive mode teaching.

\section{Intensive Mode Teaching}

For the purposes of this study, intensive mode teaching involves students attending classes on fewer days and for longer on each day than is traditional in the discipline, often only enrolled in a single course at a time. Various models of the mode have been used in business and postgraduate law courses to allow study with minimal disruption to work ${ }^{17}$. It has been used in external courses with intensive periods on campus, and in courses in health sciences to allow students to fit classes between practicums. Although the above reasons provide the impetus to use intensive mode teaching, it has been found to provide additional benefits with students and teachers in two business units and an engineering unit reporting the following opportunities for ${ }^{18,19}$;

- $\quad$ students to learn from each other and bond in a learning community $^{20}$;

- extended interactive and practical activities; and

- exposure to practice such as real-world case studies and practical application of theory in authentic contexts.

These aligned with the objectives of the course in providing field trips and building a learning community as well as incorporating the international EWB Summits.

\section{THEORETICAL FRAMEWORK}

To investigate the impacts of the intensive mode teaching threshold concept theory and threshold capability theory were used.

\section{Threshold Concepts}

Threshold concepts are critical to future learning and practice in a discipline ${ }^{21}$. They are experienced by students as transformative and usually troublesome in one of many ways. It is 
important for curriculum designers and teachers to identify threshold concepts so that they can focus on these in the curriculum, particularly in-class time.

The theory proposes that students experience a state called the "liminal space" ${ }^{, 21}$ while they still feel challenged by a threshold concept. The liminal space is rarely traversed directly and it may take students longer than one course or even a whole program of study before they overcome a threshold concept. An example of this was the "Trusteeship" threshold from an engineering concept inventory ${ }^{22}$. This was developed from work identifying a "spectrum of liminality" for the threshold of using social justice as a lens for viewing engineering ${ }^{23}$. This has five positions from the pre- to post-liminal positions connected to a threshold with nine conceptions and students' progress through the spectrum in different ways.

Threshold concepts were used in a phenomenographic study that identified seven qualitatively different student categories of understanding and experiencing of human-centred design $(\mathrm{HCD})^{24}$. A strong threshold concept was identified as a transition between the two categories not included in the main nested hierarchy. Here students need to move from technology-centred views to one where user input feeds into a linear design process. Additional transformative aspects were identified in other higher-level categories.

Threshold concept theory was valuable for studying students' learning in this study as:

- the theory is about students' experiences of learning in addition to the learning intended by the teacher;

- the concept of traversing the liminal space is relevant to a mode in which it is likely that the opportunity to traverse the liminal space is limited by time; and

- their use in related engineering education as described above.

\section{Threshold Capabilities}

Threshold capability theory has emerged from a combination of threshold concept theory and capability theory ${ }^{25}$ which proposes that students in higher education should develop capabilities to address previously unseen problems ${ }^{26}$. A threshold capability is transformative and challenging, and critical to future progress, as is a threshold concept. A threshold capability is likely to depend on understanding of one or more threshold concepts. The liminal space also applies to threshold capabilities.

\section{Research Questions}

Building on the theoretical framework established, three research questions were identified for evaluating the course:

1. what did students identify as thresholds for the course?

2. what features of the course hindered or supported their learning?

3. what were the benefits and limitations of the delivery mode as preparation for humanitarian engineering service-learning?

\section{COURSE DeVELOPMENT}

\section{Course Design}

The development of the course utilised a version of the systems engineering vee design process applied to education ${ }^{11,27}$. First a set of learning outcomes were developed with input from external partners which was then peer-reviewed. These were used to drive the development of a set of course topics, each with corresponding learning outcomes, organised to give the structure of the course. The four main topics were Humanitarian Contexts, Humanitarian Approaches and Models, Personal Practice and Engineering Practice. Within 
these were 17 sub-topics and a total of 70 individual topics. Teaching and learning activities were developed to meet each individual topic's outcome, taking into account the opportunities presented by the intensive mode teaching. Constructive alignment was used to validate and align assessment, topics and outcomes. This approach resulted in a very fine level of course content detail meaning individual activities could be modified or changed as long as the outcomes were still met. This allowed the course to be delivered to two cohorts, one entirely based on-campus (although including site visits), the other off-campus incorporating the two-week international EWB Summit.

\section{Course Delivery}

The total number of students who undertook the course is shown in Table 1. All undergraduate students were enrolled in either a single four-year bachelor of engineering degree or a five-year double degree including engineering. The masters coursework students were all enrolled in a Master of Engineering program.

TABLE 1

STUDENT ENROLMENTS BY DELIVERY MODE AND DEGREE PROGRAM

\begin{tabular}{|l|c|}
\hline \multicolumn{1}{|c|}{ Student Cohort } & Enrolments \\
\hline Campus Based - Undergraduate & 36 \\
\hline Campus Based - Postgraduate & 3 \\
\hline With EWB Design Summit - Undergraduate & 8 \\
\hline Total & 46 \\
\hline
\end{tabular}

The course was available as a special topic, meaning enrolment was by approval of the course coordinator. The pre-requisites were either a bachelor's degree or two-years of undergraduate engineering. One exception was made to this, for a second year student, due to their significant background with development work and excellent academic performance. No students who had completed the pre-requisites were refused enrolment.

\section{Course Delivery - On-Campus}

The on-campus delivery was during the June-July winter term between the main teaching semesters. The course had four weeks of delivery, each with on average $2 \frac{1}{2}$ days of class time, followed by a week for completing and presenting assessment. A mix of learning activities was used each day, covering practical sessions, class discussions, seminars and guest presentations. The eight guests involved were drawn from engineering with significant humanitarian experience, non-engineers with backgrounds in development studies, and those with lived experience of humanitarian responses. Three site visits were conducted, all with an hour transit. Two of these were 2-3 hour visits to organisations involved with humanitarian work with discussions focused on their approach and operations. The other was a full day visit to a nature reserve, Birrigai, exploring Indigenous knowledge and undertaking a 'learning track' with an Indigenous Australian ranger.

\section{Course Delivery - Off-Campus}

Students incorporating the EWB Summit in the course had a different course structure although the same learning outcomes and assessment tasks ${ }^{11}$. Delivery consisted of a oneday workshop with students before they left. The Summit ran for two weeks in Cambodia, with a total of 40 participants from multiple universities around Australia. Participants started with workshops in Phnom Penh and engaged in cultural experiences. The Summit 
split into three groups, each spending four days on a rural community visit working with a Cambodian-based community organisation. The focus was on human-centred design and identifying challenges and opportunities student teams could develop concepts and ideas for. The three teams then re-joined and spent further time working on their concepts. Finally, concepts were presented back to the community organisations for their consideration and feedback to support knowledge transfer and identify any potential next steps. For the course, students returned and completed another half-day workshop on campus and presented their final assignments with students from the campus-based delivery.

\section{METHODS}

Data collection methods are outlined in the sub-sections below in the sequence in which they were conducted, labelled for reference later in this paper. A two-phase approach adapted from one to identify threshold concepts and capabilities was used ${ }^{28}$. The first phase (B and C below) was exploratory and identified potential threshold concepts and capabilities. In the second refinement phase $(\mathrm{G}$ and $\mathrm{H})$, identified thresholds were negotiated with the teaching team and reduced for a student survey. Data collected through student course evaluations (A, D-F) were used to support and validate findings.

Across all data collection, participants were drawn from the course only, and all participation was voluntary and anonymous. Ethics approval was provided by the home institution (for A, D-F) and the lead institution for the intensive mode teaching research (for $\mathrm{B}, \mathrm{C}, \mathrm{G}$ and $\mathrm{H})$.

\section{A. Student Entry Survey}

An online entry survey was used to capture student background before the course. This included information to help shape elements of the course as well as enrolment motivations.

\section{B. Interviews with Teaching Team}

The course coordinator at the home institution and external person at EWB involved with development, as a content expert, were interviewed as part of the exploratory phase. Interviews were semi-structured, 45 minutes long and recorded and transcribed. The interviewer explained the theory to the participant. Interview questions were:

1. What is your role in the unit?

2. In this role, have you noticed that students experience any threshold concepts in this unit?

3. What makes you think that students find this concept troublesome?

4. One or more threshold concepts can be combined to achieve a 'threshold capability'. With a threshold capability students can apply understanding of threshold concepts to previously unseen problems. Like threshold concepts, threshold capabilities are critical to future learning and practice in the discipline.

5. Can you think of a threshold capability in your unit?

6. Please think of one threshold capability that is especially troublesome.

7. What are you aware that students do to help them develop this capability?

8. What about the teaching and/or about students assists them to overcome the threshold?

9. What about the teaching and/or students hindered them in overcoming the threshold? 


\section{In-class Student Workshop}

Also in the exploratory phase, a 30 minute in-class workshop was held during week three of the class by an independent researcher, during which the course coordinator was not present. It was not recorded as students were able to participate without agreeing to take part in the study although the researcher did take hand-written notes. The researcher explained the theory to participants and facilitated a discussion asking open questions to ensure the students understood the theory. Students were invited to complete a questionnaire to collect demographic data and a second questionnaire containing the following questions:

1. Please identify a threshold concept that you have experienced in the unit.

2. Please describe a threshold capability that you have experienced in the unit. It might be an application of the threshold concept identified above, or a different capability.

3. How was the capability troublesome?

4. What did you do to develop the capability?

5. Please identify any feature of the unit that helped you to develop the capability.

6. Please identify anything about you (such as your strengths, experience, or support) that helped you to develop the capability.

7. Please identify any feature of the unit that hindered you in developing the capability.

8. Please identify anything about you (such as your experience or commitments) that hindered you in developing the capability.

Responses from B and C were analysed for evidence of potential threshold concepts or capabilities, how these were transformative and troublesome, and factors that supported and hindered overcoming them. Coding was managed using NVivo ${ }^{\mathrm{TM}}$ V10.

\section{In-class Discussion}

In the last session of the course an in-class feedback discussion was led by the course coordinator. Students identified course highlights, which of the course learning outcomes they felt they had achieved, and additional topics or ideas for inclusion.

\section{E. Student Exit Survey}

An anonymous paper based exit survey was used to capture student feedback. This was conducted after students had given their final assessment presentations.

\section{F. Student Course Evaluations}

All courses at ANU are required to incorporate two formal course evaluations, student experiences of learning and teaching. These are anonymous online surveys with a combination of 5 point scales and open ended questions set by the university. Separate surveys are used for undergraduate and postgraduate students, as assessment items and criteria vary slightly for these cohorts. The survey is opened after the delivery of the course and closed before final results are released.

\section{G. Post-Completion Focus Group with Teaching Team}

After the students had received their results for the unit, the course coordinator and external person at EWB were interviewed together for 45 minutes. In this interview they were presented with themes identified in the exploratory stage. They clarified features of the 
course mentioned by students and reduced the themes to a selection of items for a student survey. This included the main threshold capability and features raised by students as supporting and hindering them in overcoming thresholds in the course.

\section{H. Post-Completion Student Survey}

Students in the course were invited by email to complete an online survey. The survey included demographic questions and the questions below designed to assess the extent to which participants experienced the identified main threshold capability as transformative and challenging. The items were developed directly from the theory, the exploratory phase in this study, and themes identified in other intensive mode engineering and business units ${ }^{19}$.

\section{RESUltS}

Results are provided below across three main activities, from the exploratory phase on threshold concepts (methods B and C), from the post-completion threshold capability student survey $(\mathrm{H})$, and the student input methods (A, D to F). Response rates are provided in Table 2 giving overall rates and distributions for students involved in on- and off-campus (attended the EWB Summit) delivery while demographic profiles for each method are summarised in Table 3. Method F could not include a question on delivery mode as this was a standard university-wide evaluation.

TABLE 2

DATA COLLECTION RESPONSE RATES AND DISTRIBUTION FOR ON- AND OFF-CAMPUS DELIVERY

\begin{tabular}{|c|c|c|c|c|}
\hline & & $\mathbf{N}$ & $\begin{array}{l}\text { Response } \\
\text { Rate \% }\end{array}$ & $\begin{array}{l}\text { Distribution \% } \\
\text { of Respondents }\end{array}$ \\
\hline \multirow[t]{3}{*}{ A. Student Entry Survey } & $\begin{array}{llll}\begin{array}{l}\text { Overall } \\
\text { students) }\end{array} & \text { (potential participants } & 46 \\
\end{array}$ & 37 & 80.4 & \\
\hline & $\begin{array}{l}\text { Did Not Attended Summit As Part of } \\
\text { Course }\end{array}$ & 36 & 94.7 & 93.0 \\
\hline & Attended Summit As Part of Course & 1 & 12.5 & 7.0 \\
\hline \multirow[t]{3}{*}{ C. In-Class Workshop } & $\begin{array}{lrlr}\begin{array}{l}\text { Overall } \\
\text { students on-campus) }\end{array} & \text { potential } & \text { participants } & 38 \\
\end{array}$ & 28 & 73.7 & \\
\hline & $\begin{array}{l}\text { Did Not Attended Summit As Part of } \\
\text { Course }\end{array}$ & 28 & 73.7 & 100.0 \\
\hline & Attended Summit As Part of Course & 0 & 0.0 & 0.0 \\
\hline \multirow[t]{3}{*}{ D. In-Class Discussion } & $\begin{array}{lrlr}\begin{array}{l}\text { Overall } \\
\text { students on-campus) }\end{array} & \text { participants } & \mathbf{3 8} \\
\end{array}$ & 21 & 55.3 & \\
\hline & $\begin{array}{l}\text { Did Not Attended Summit As Part of } \\
\text { Course }\end{array}$ & 21 & 55.3 & 100.0 \\
\hline & Attended Summit As Part of Course & 0 & 0.0 & 0.0 \\
\hline \multirow[t]{3}{*}{ E. Student Exit Survey } & $\begin{array}{l}\text { Overall (potential participants to all } 46 \\
\text { students) }\end{array}$ & 39 & 84.7 & \\
\hline & $\begin{array}{l}\text { Did Not Attended Summit As Part of } \\
\text { Course }\end{array}$ & 33 & 86.8 & 84.6 \\
\hline & Attended Summit As Part of Course & 6 & 75.0 & 15.4 \\
\hline F. Course Evaluation & $\begin{array}{llll}\begin{array}{l}\text { Overall (potential } \\
\text { undergraduates) }\end{array} & \text { participants } & 43 \\
\end{array}$ & 17 & 39.5 & \\
\hline \multirow[t]{3}{*}{$\begin{array}{ll}\text { H. } & \text { Post-Completion } \\
\text { Survey } & \\
\end{array}$} & $\begin{array}{llll}\begin{array}{l}\text { Overall } \\
\text { students) }\end{array} & \text { (potential participants } & 46 \\
\end{array}$ & 20 & 43.5 & \\
\hline & $\begin{array}{l}\text { Did Not Attended Summit As Part of } \\
\text { Course }\end{array}$ & 12 & 31.6 & 60.0 \\
\hline & Attended Summit As Part of Course & 8 & 100.0 & 40.0 \\
\hline
\end{tabular}


International Journal for Service Learning in Engineering,

Humanitarian Engineering and Social Entrepreneurship

Vol. 11, No. 2, pp. 38-54, Fall 2016

ISSN 1555-9033

TABLE 3

PARTICIPANT DEMOGRAPHIC PROFILES

\begin{tabular}{|c|c|c|c|}
\hline A. Student Entry Survey & Characteristic & $\mathbf{N}$ & $\%$ \\
\hline & Respondents and response rate (available to all 46 students) & 37 & 80.4 \\
\hline & Year Level & & \\
\hline & First & 0 & 0.0 \\
\hline & Second & 1 & 2.7 \\
\hline & Third & 7 & 18.9 \\
\hline & Fourth & 25 & 67.6 \\
\hline & Fifth & 1 & 2.7 \\
\hline & Masters Coursework & 3 & 8.1 \\
\hline & Discipline Major & & \\
\hline & Electronic and Communication Systems & 9 & 24.3 \\
\hline & Mechanical and Material Systems & 24 & 64.9 \\
\hline & Mechatronic Systems & 3 & 8.1 \\
\hline & Renewable Energy Systems & 8 & 21.6 \\
\hline & Sustainable Systems & 2 & 5.4 \\
\hline & Digital Systems and Telecommunications & 2 & 5.4 \\
\hline C. In-Class Workshop & Characteristic & $\mathbf{N}$ & $\%$ \\
\hline & Respondents and response rate (from 39 students on-campus) & 28 & 71.8 \\
\hline & Gender & & \\
\hline & Female & 9 & 32.1 \\
\hline & Male & 19 & 67.9 \\
\hline & Enrolment & & \\
\hline & Domestic & 14 & 50.0 \\
\hline & International & 14 & 50.0 \\
\hline & Age range 20 to 26 years $(M=22.2$ years, $S D=1.5$ years $)$ & & \\
\hline D. In-Class Discussion & Characteristic & $\mathbf{N}$ & $\%$ \\
\hline & Respondents and response rate (from 39 students on-campus) & 21 & 53.8 \\
\hline E. Student Exit Survey & Characteristic & $\mathbf{N}$ & $\%$ \\
\hline & Respondents (available to all 46 students) & 39 & 84.7 \\
\hline & Gender & & \\
\hline & Female & 12 & 36.4 \\
\hline & Male & 21 & 63.6 \\
\hline F. Course Evaluation & Characteristic & & \\
\hline & Respondents and response rate (from 43 undergraduates) & 17 & 39.5 \\
\hline & Enrolment & & \\
\hline & Domestic & 9 & 52.9 \\
\hline & International & 8 & 47.1 \\
\hline & Full-time student & 17 & 100.0 \\
\hline & Part-time student & 0 & 0.0 \\
\hline H. Post-Completion & Characteristic & $\mathbf{N}$ & $\%$ \\
\hline & Respondents and response rate (available to all 46 students) & 20 & 43.5 \\
\hline & Gender & & \\
\hline & Female & 8 & 40.0 \\
\hline & Male & 12 & 60.0 \\
\hline & Enrolment & & \\
\hline & Domestic & 15 & 75.0 \\
\hline & International & 5 & 25.0 \\
\hline & Age range 20 to 25 years $(M=22.0$ years, $S D=1.2$ years $)$ & & \\
\hline
\end{tabular}




\section{Threshold Concept Workshop Themes}

Themes indicating threshold concepts and capabilities are presented in Table 4. These were identified in the questionnaire responses from students from the in-class workshop (method C) for the following question: Referring to the capability to take account of social factors in engineering designs, please rate your agreement with each of the following statements $(1=$ Strongly disagree; 5 = Strongly agree.)

TABLE 4

THRESHOLDS EXPERIENCED BY STUDENTS

\begin{tabular}{llrl}
\hline Threshold Concept & Sample Comments & Comment & 8 \\
\hline $\begin{array}{l}\text { Definition of humanitarian } \\
\text { engineering }\end{array}$ & $\begin{array}{l}\text { The definition of humanitarian engineering encompassing } \\
\text { development and disability, not just disaster relief. }\end{array}$ & 4 \\
Relevance of social cultural & $\begin{array}{l}\text { Understanding that different experiences, be it social, cultural, } \\
\text { environmental, affect the engineering process }\end{array}$
\end{tabular}
and environmental context environmental, affect the engineering process.

to engineering

Threshold Capability Sample Comments Comments

Communication with others Being able to understand how to convey complex engineering

Ability to identify when each approach may be appropriate, given the context of the problem, and how that changes the technology.

The second of the capabilities in Table 4 was reduced to the more specific capability "to take account of social factors in engineering design" to provide the main subject to focus students' attention on their experience of learning in the unit in the final student survey (method $\mathrm{H}$ ). The more specific capability satisfied the principle for questionnaire designs that each question must ask only one clear question to avoid collecting responses with ambiguous meanings. 


\section{Threshold Capability Survey Results}

The first survey questions in method $\mathrm{H}$ were to describe the generalisability of the experience of the capability "to take account of social factors in engineering design" as a threshold by students in the unit. Results are presented in Table 5 including an overall 4 or 5 response rate for the class, as well as 4 or 5 response rates from students with on- and off-campus experiences, in addition to an exact significance test comparing the two cohorts' responses for each statement.

TABLE 5

RATINGS OF AGREEMENT WITH STATEMENTS REGARDING THE CAPABILITY “TO TAKE ACCOUNT OF SOCIAL FACTORS IN ENGINEERING DESIGN” $(N=20)$

\begin{tabular}{|l|l|l|l|l|l|}
\hline Statement & $\begin{array}{l}\mathbf{4} \text { or } \\
\text { selected } \\
\text { student }\end{array}$ by & $\begin{array}{l}\text { \% } \\
\text { Overall }\end{array}$ & $\begin{array}{l}\text { On- } \\
\text { Campus }\end{array}$ & $\begin{array}{l}\text { Off- } \\
\text { Campus }\end{array}$ & p \\
\hline $\begin{array}{l}\text { In this unit I developed the capability to } \\
\text { take account of social factors in engineering } \\
\text { designs }\end{array}$ & 20 & 100 & 100 & 100 & 1.00 \\
\hline $\begin{array}{l}\text { This learning transformed my thinking } \\
\text { about engineering design. }\end{array}$ & 19 & 95.0 & 91.7 & 100 & 1.00 \\
\hline $\begin{array}{l}\text { This learning transformed my thinking } \\
\text { about the kind of engineer I hope to be. }\end{array}$ & 17 & 85.0 & 75.0 & 100 & 0.24 \\
\hline $\begin{array}{l}\text { This learning challenged my previous } \\
\text { assumptions. }\end{array}$ & 13 & 65.0 & 50.0 & 87.5 & 0.16 \\
\hline $\begin{array}{l}\text { I needed to commit much time for this } \\
\text { learning. }\end{array}$ & 9 & 45.0 & 50.0 & 37.5 & 0.67 \\
\hline The capability is still challenging for me. & 4 & 19.0 & 16.7 & 25.0 & 1.00 \\
\hline $\begin{array}{l}\text { Learning to communicate with people from } \\
\text { outside engineering or other cultures was } \\
\text { challenging. }\end{array}$ & 8 & 40.0 & 16.7 & 75.0 & $0.02 *$ \\
\hline $\begin{array}{l}\text { Understanding the meaning of engineering } \\
\text { practice was challenging. }\end{array}$ & 4 & & & & \\
\hline $\begin{array}{l}\text { Understanding the meaning of humanitarian } \\
\text { engineering was challenging. }\end{array}$ & 9 & 19.0 & 16.7 & 35.0 & 1.00 \\
\hline $\begin{array}{l}\text { Dealing with loosely defined problems was } \\
\text { challenging. }\end{array}$ & 9 & 42.9 & 41.7 & 50.0 & 1.00 \\
\hline
\end{tabular}

Notes for Table 5:

1. Student rated statement on a five-point scale $(1=$ strongly disagree; $5=$ strongly agree)

2. Items are listed in the order they were presented in the questionnaire.

3. $\quad N$ for on-campus was 12 (from 38 potential respondents) and off-campus was 8 (from 8 potential respondents).

4. $p$ is calculated using Fisher's exact test.

5. $p$ of less than 0.05 are marked with an $*$ and are considered significant.

Students responded to the following question for ratings of factors that supported and hindered their development of the capability "to take account of social factors in engineering design" for items shown in Figures 1 and 2. Please rate the extent to which each of the following factors influenced your development of the capability to take account of social factors in engineering designs $(1=$ Strongly hindered your development of the capability; 7 $=$ Strongly supported your development of the capability). In the text boxes please explain any ratings of 1 or 7 . 
Loosely defined problems in assessments The time between classes

The duration of class-time per day

Set reading material

The number of assessments

The timing of the unit between semesters

Opportunity to practice (in or out of class)

The timing of feedback from assessments

Interactive group activities

Support to reflect on your learning

Build workshops

Extended discussions in class

The breaks during class

Opportunity for you to learn from peers

Opportunity to source information from outside..

Opportunity for you to ask questions in class

The number of students in a class

Guest speakers

Real-world case studies

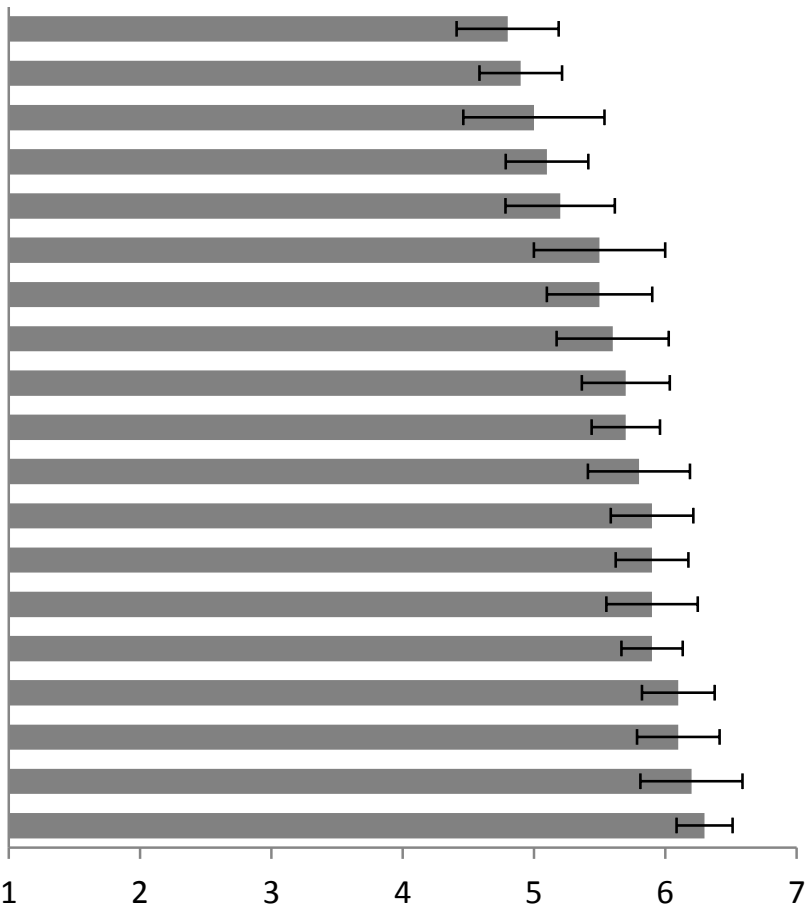

Extent to which the factor influenced your development of the capability (1 = Strongly hindered your development of the capability; 7 = Strongly supported your development of the capability) $(M+/-S E)$

\section{FIGURE 1}

RATINGS OF THE EXTENT TO WHICH FACTORS INFLUENCED DEVELOPMENT OF THE CAPABILITY BY STUDENTS WHO DID NOT ATTEND THE EWB SUMMIT FOR THE UNIT ( $N=10$ FROM 38 POTENTIAL RESPONDENTS) (NO MISSING

VALUES)

\section{Student Input}

The primary motivations of students from the entry survey, where students could only select one option, are shown in Table 6 and highlights more than half $(56.7 \%)$ of the students were primarily interested in the topic of the course rather than the delivery mode or timing.

TABLE 6

PRIMARY STUDENT MOTIVATIONS FOR ENROLMENT

\begin{tabular}{|l|c|c|}
\hline Primary Motivation & $\mathbf{N}$ & $\mathbf{\%}$ \\
\hline Interested in humanitarian engineering & 12 & 32.4 \\
\hline Interested in the application of engineering to real-world problems & 9 & 24.3 \\
\hline Reduced course load in semester 2 & 9 & 24.3 \\
\hline Convenience & 3 & 8.1 \\
\hline Just need one course to finish studies & 2 & 5.4 \\
\hline Other & 2 & 5.4 \\
\hline
\end{tabular}


Three separate methods provided data to identify the highlights or strengths of the course, the in-class discussion on the last delivery day (method D), the exit survey (E) after the final assessment item and the formal Student Experience of Learning (SEL) survey (F). Highlights identified from these as shown in Table 7.

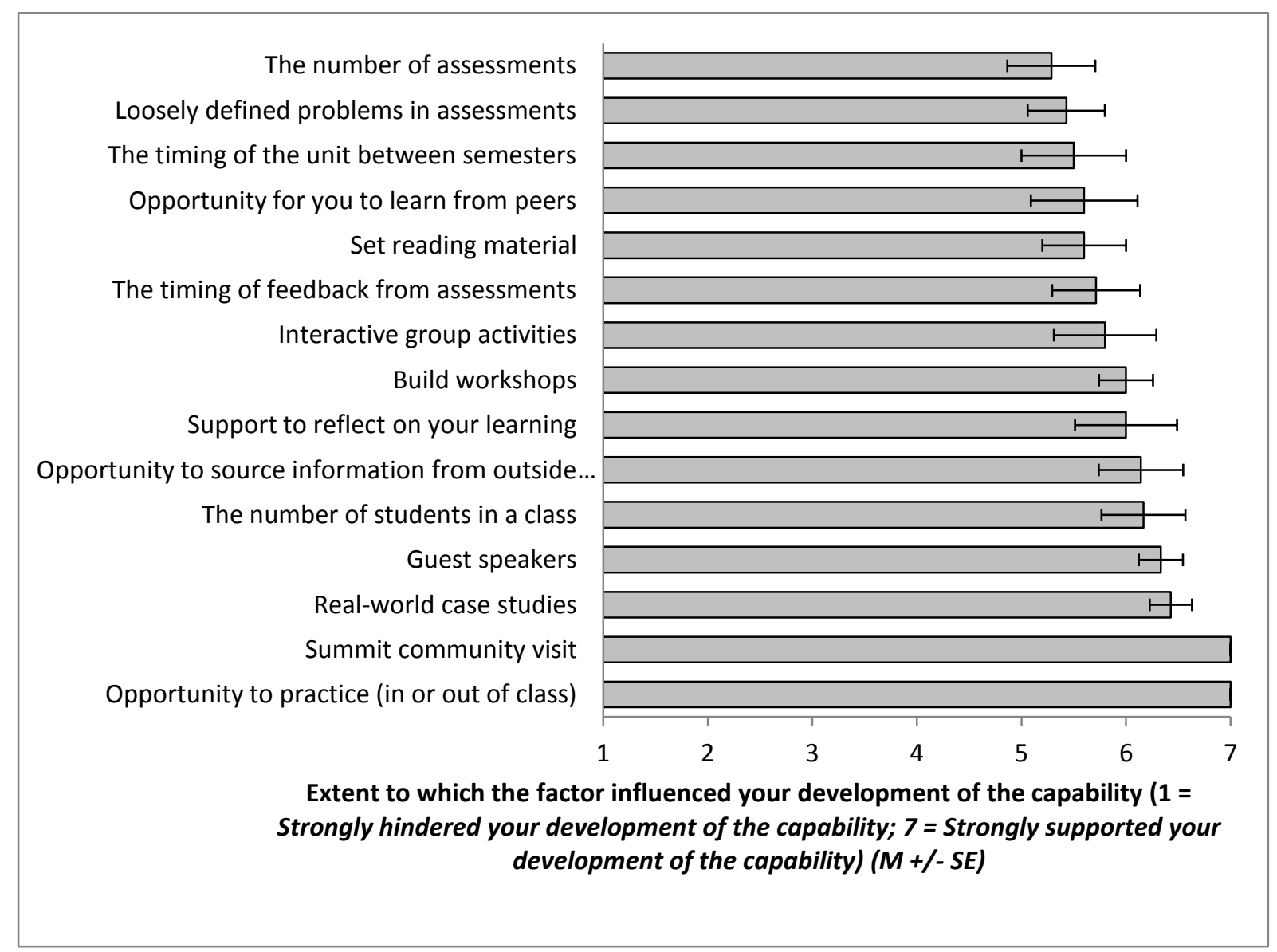

FIGURE 2

RATINGS OF THE EXTENT TO WHICH FACTORS INFLUENCED DEVELOPMENT OF THE CAPABILITY BY STUDENTS WHO ATTENDED THE EWB SUMMIT FOR THE UNIT (N = 8 FROM 8 POTENTIAL RESPONDENTS WITH 13 OR 12.4\% OF MISSING VALUES)

TABLE 7

COURSE HIGHLIGHTS AND STRENGTHS IDENTIFIED BY STUDENTS

\begin{tabular}{|l|l|}
\hline \multicolumn{1}{|c|}{ Course Highlight } & \multicolumn{1}{c|}{ Method Identify From } \\
\hline Birrigai Field Trip (Indigenous Focus) & In-class \\
\hline Field Trips & In-class, SEL \\
\hline Build Workshops & In-class, Exit Survey, SEL \\
\hline Social Aspects (Learning Community) & In-class \\
\hline Class Discussion Sessions & In-class, Exit Survey \\
\hline Guest Lectures or Workshops & In-class, Exit Survey, SEL \\
\hline EWB Summit & Exit Survey, SEL \\
\hline
\end{tabular}

The formal course evaluations are provided in Table 8, with the score out of 5 and the agreement rate consisting of those that 'agree' or 'strongly agree' with the question (4 or 5). 
Only responses from undergraduate students are provided, as the three enrolled postgraduate students was less than the five required by the university to release results. As this was an university administered evaluation, a question on the delivery mode could not be included.

TABLE 8

FORMAL STUDENT EVALUATIONS OF THE COURSE

\begin{tabular}{|c|c|c|c|}
\hline Evaluation & $\begin{array}{c}\text { Score } \\
\text { (out of 5) }\end{array}$ & $\begin{array}{c}\text { Agreement Rate } \\
(\mathbf{\%})\end{array}$ & $\begin{array}{c}\text { Response Rate } \\
(\boldsymbol{\%})\end{array}$ \\
\hline Experience of Learning (SEL) & 4.8 & 100 & 40 \\
\hline Experience of Teaching (SET) & 4.9 & 100 & 40 \\
\hline
\end{tabular}

Key limitations or areas for improvement for the course identified by students were mostly on assignments including the clarity of rubrics, expectations and time available, the latter of which is a function of the intensive teaching mode.

\section{DISCUSSION}

The strong formal student evaluations in Table 8 as well as the exit survey and in-class discussions and results from Table 5 indicate the course provided new learning for students. Results are discussed below corresponding to the three research questions posed for the study.

\section{Thresholds Identified}

The results indicate the capability identified, "to take account of social factors in engineering design", was a threshold, as students had not previously considered taking social factors into account in their engineering design. Responses from the post-completion survey (method $\mathrm{H}$ ) and Table 5, confirm that the capability was transformative for $95.0 \%$ of the student survey participants and troublesome for $65.0 \%$ of students survey participants. Furthermore, a majority $(81.0 \%)$ of the students no longer found the capability challenging and therefore had probably traversed the liminal space for this capability by the end of the course. The reasons students found the capability troublesome varied, as highlighted by Figures 1 and 2 .

Differences between students who attended the EWB Summit (off-campus) and those who did not (on-campus) can been seen in Figures 1 and 2, and Table 5 where a trend can be seen. Those who attended the EWB Summit had potentially a more challenging but richer learning experience. However, only one statement can be considered significant, referring to learning to communicate was challenging. Students on the Summit were in a foreign culture with a different language, which required the use of translators which would have contributed to the significant difference between the two cohorts here.

The thresholds experienced by students were consistent with other studies. The main threshold capability relates to those identified in the threshold concept inventory ${ }^{22}$ in particular the "Roles of engineers". This includes elements of "responsibility of engineers to society, the environment, and workers" and "value of an engineer to society and to organisations".

\section{Contributions of Course Features to Learning}

For campus-based students, a number of activities enabled by the intensive mode teaching were strong contributing factors to the development of capability. From Figure 1, site visits were the equal forth highest contributing factor. Other factors that can be incorporated into 
most teaching modes but are more easy to accommodate in intensive mode teaching scored well, specifically guest speakers (second highest) and opportunities to ask questions in class (third highest). Day or half-day face-to-face sessions provided more opportunity to accommodate guests and flexibility to change activities based on student engagement and interest such as further class discussion and questioning.

Across all students, the factor that was identified as contributing most to the development of the capability was the community visit undertaken in the EWB Summit (Figures 1 and 2). This highlights the role of external engagement in achieving the capability identified. Other activities that can support transformations here including real-world case studies, guest speakers and site visits, all scored highly in influencing the development of the capability. The exposure to real-world applications through guest lectures and case studies were rated most supportive for learning after the Summit (Figures 1 and 2).

Although the response rate for the post-completion survey was not quite half the class (43.5\%), the findings from this method are supported by both the in-class discussions and exit survey (see Table 7). The findings are also consistent with existing work in the area with respect to intensive teaching mode $\mathrm{e}^{18,20,28}$.

\section{Contributions of Delivery Mode to Service-Learning Preparation}

The course was established to help prepare students for more substantial service-learning initiatives related to humanitarian engineering. The threshold capability identified, "to take account of social factors in engineering design", appears well suited as a threshold to achieve as preparation for service-learning. In terms of students achieving this threshold and then moving to more substantive service-learning, a number of students participating in the course have gone on to take part in final year service-learning projects. Of the 43 undergraduates in the course, three were already involved in final year service-learning projects while four have commenced projects at the start of the 2016 academic year.

The inclusion of the EWB Summit in particular has aligned with the development of the pathway leading to service-learning experiences. From twelve students who undertook an EWB Summit over the 2015/16 Australian summer (not part of this study), five have commenced service-learning final year individual research projects in 2016 while another two will once they reach their final year in 2017. With the community visit on the Summit as the factor that most contributed to achieving the threshold this is appropriate preparation for students. The development of a student pathway may support opportunities for student development of thresholds from multiple engagements and opportunities to move through the liminal space ${ }^{23}$.

\section{CONCLUSIONS, RECOMMENDATIONS AND CONTINUING WORK}

Intensive mode teaching was found to provide opportunities for significant contributions to the threshold identified by students for the course, "to take account of social factors in engineering design". With these findings, the choice to deliver the course using intensive mode teaching is supported as the activities achievable made significant contributions to students' development of the capability. The teaching mode supported the inclusion of the international EWB Summit which included a community visit which was the factor that contributed most to the capability development.

There is a need to evaluate students' outcomes within the broader context of their overall studies. This needs to consider how the course provided preparation for later service-learning initiatives in terms of the outcomes achieved through the service-learning experience. This is 
the focus of current research at ANU with students involved in the course or who have attended an EWB Summit.

The research framework utilised here may have further benefit for evaluating servicelearning. Many staff have observed the "transformative" nature of service-learning, and threshold concepts and capabilities may provide a framework to help identify key thresholds.

\section{ACKNOWLEDGEMENT}

The authors wish to thank all the students who undertook the course and provided feedback. Support was provided for the development and delivery of the course and the evaluation of the intensive mode teaching by the Australian Government Office for Learning and Teaching. The views expressed here do not necessarily reflect the views of the Australian Government Office for Learning and Teaching.

\section{REFERENCES}

1 Sandekian, R., Chinowsky, P., \& Amadei, B. (2014). Engineering for Developing Communities at the University of Colorado Boulder: A Ten Year Retrospective. International Journal for Service Learning in Engineering, Humanitarian Engineering and Social Entrepreneurship, 62-77.

2 Colledge, T. H. (2014). Engineering and Engaged Scholarship at Penn State Part II: The Existing Ecosystem. International Journal for Service Learning in Engineering, Humanitarian Engineering and Social Entrepreneurship, 114-147.

3 Pinnell, M., Daniels, M., Hallinan, K., \& Berkemeier, G. (2014). Leveraging Students' Passion and Creativity: ETHOS at the University of Dayton. International Journal for Service Learning in Engineering, Humanitarian Engineering and Social Entrepreneurship, 180-190.

4 Bixler, G., Campbell, J., Dzwonczyk, R., Greene, H. L., Merrill, J., \& Passino, K. M. (2014). Humanitarian Engineering at The Ohio State University: Lessons Learned in Enriching Education While Helping People. International Journal for Service Learning in Engineering, Humanitarian Engineering and Social Entrepreneurship, 78-96.

5 Zoltowski, C. B., \& Oakes, W. C. (2014). Learning by doing: reflections of the EPICS program. International Journal for Service Learning in Engineering, Humanitarian Engineering and Social Entrepreneurship, 1-32.

6 Bielefeldt, A., Paterson, K., \& Swan, C. (2009). Measuring the Impacts of Project-Based Service Learning. American Society for Engineering Education.

7 Bielefeldt, A. R., \& Canney, N. (2014). Impacts of Service-Learning on the Professional Social Responsibility Attitudes of Engineering Students. International Journal for Service Learning in Engineering, Humanitarian Engineering and Social Entrepreneurship, 9(2), 47-63.

8 Bielefeldt, A., Paterson, K. G., \& Swan, C. W. (2010). Measuring the Value Added from Service Learning in Project-Based Engineering Education. International Journal of Engineering Education, (3), 535-546.

9 Astin, A. W., Vogelgesang, L. J., Misa, K., Anderson, J., Denson, N., Jayakumar, U., Yamamura, E. (2006). Understanding the effects of service-learning: A study of students and faculty. Report to the Atlantic Philanthropies, 1-155.

${ }^{10}$ Hill, S., \& Miles, L. (2012). What do Students understand by the term 'Humanitarian Engineering'? In Innovation, Practice and Research in Engineering Education (pp. 1-11). Coventry University, UK.

${ }^{11}$ Smith, J., Turner, J., \& Brown, N. (2015). Design for Dissemination - Development of a Humanitarian Engineering Course for Curriculum Sharing. In 26th Annual Conference of the Australasian Association for Engineering Education (AAEE1015) Order of Proceedings.

12 Nieusma, D., \& Riley, D. (2010). Designs on development: engineering, globalization, and social justice. Engineering Studies, 2(1), 29-59. http://doi.org/10.1080/19378621003604748 
13 Bielefeldt, A., Paterson, K. G., Swan, C. W., Pierrakos, O., Kazmer, D. O., \& Soisson, A. (2013). Spectra of Learning Through Service Programs. Presented at the 120th ASEE Annual Conference and Exposition, Atlanta.

${ }^{14}$ Duffy, J., Barry, C., Barrington, L., \& Heredia, M. (2009). Service-learning in engineering science courses: Does it work? In American Society for Engineering Education. American Society for Engineering Education.

15 Vandersteen, J. D. J., Baillie, C., \& Hall, K. (2009). International humanitarian engineering. IEEE Technology and Society Magazine, 28(4), 32-41.

16 Smith, J., Turner, J., Brown, N., \& Price, J. (2016). Integration of a short-term international humanitarian engineering experience into engineering undergraduate studies. In ASEE's 123rd Annual Conference and Exposition.

17 Davies, W. M. (2006), "Intensive teaching formats: A review", Issues in Educational Research, Vol. 16 (1), pp. 1-18.

18 Crispin, S., Hancock, P., Male, S. A., Baillie, C., MacNish, C., Leggoe, J., Alam, F. (2016). Threshold capability development in intensive mode business units. Education \& Training, 58(5). pp 1-23, doi: 10.1108/et-02-2016-0033

19 Male, S. A., Baillie, C., Alam, F., Crispin, S., Hancock, P., Leggoe, J., Ranmuthugala, D. (2016). Students' experiences of threshold capability development with intensive mode teaching. Paper presented at the 39th Annual Conference of the Higher Education Research and Development Society of Australasia (HERDSA), Fremantle, Western Australia.

20 Wenger, E. (1998). Communities of Practice - Learning, Meaning and Identity. New York: Cambridge University Press.

${ }^{21}$ Meyer, J. H. F., \& Land, R. (2003). Enhancing Teaching-Learning Environments in Undergraduate Courses Occasional Report 4 Retrieved 31 May 2010, from http://www.etl.tla.ed.ac.uk/docs/ETLreport4.pdf

22 Male, S. A. (2012). Engineering Thresholds: an Approach to Curriculum Renewal Final Report. Sydney: Australian Government Office for Learning and Teaching.

${ }^{23}$ Kabo, J., \& Baillie, C. (2009). Seeing through the lens of social justice: a threshold for engineering. European Journal of Engineering Education, 34(4), 317 - 325.

${ }^{24}$ Zoltowski, Carla B., William C. Oakes, and Monica E. Cardella. 'Students' Ways of Experiencing Human-Centered Design'. Journal of Engineering Education 101, no. 1 (1 January 2012): 28-59. doi:10.1002/j.2168-9830.2012.tb00040.x.

25 Bowden, J. A. (2004). Capabilities-driven curriculum design. In C. Baillie \& I. Moore (Eds.), Effective learning \& teaching in engineering (pp. 36-47). Abingdon, Oxon: RoutledgeFalmer.

26 Baillie, C., Bowden, J. A., \& Meyer, J. H. F. (2013). Threshold Capabilities: threshold concepts and knowledge capability linked through variation theory. Higher Education, 65(2), 227-246.

${ }^{27}$ Faulconbridge, R. I., \& Dowling, D. (2010). Systems approach to engineering education design. In Proceedings of the 2010 Systems Engineering/Test and Evaluation Conference (SETE 2010). Systems Engineering Society of Australia.

28 Male, S. A., \& Baillie, C. A. (2011). Threshold Concept Methodology. Paper presented at the Research in Engineering Education Symposium, Madrid. 